22. Cao B, Huang GH, Pu ZH, Qu JX, Yu XM, Zhu Z, et al. Emergence of community-acquired adenovirus type 55 as a cause of community-onset pneumonia. Chest. 2014;145:79-86. http://dx.doi.org/10.1378/chest.13-1186

23. Lafolie J, Mirand A, Salmona M, Lautrette A, Archimbaud C, Brebion A, et al. Severe pneumonia associated with adenovirus type 55 infection, France, 2014. Emerg Infect Dis. 2016;22:2012-4. http://dx.doi.org/10.3201/eid2211.160728

24. Kim YJ, Hong JY, Lee HJ, Shin SH, Kim YK, Inada T, et al. Genome type analysis of adenovirus types 3 and 7 isolated during successive outbreaks of lower respiratory tract infections in children. J Clin Microbiol. 2003;41:4594-9. http://dx.doi.org/ 10.1128/JCM.41.10.4594-4599.2003

25. Lee J, Choi EH, Lee HJ. Clinical severity of respiratory adenoviral infection by serotypes in Korean children over 17 consecutive years (1991-2007). J Clin Virol. 2010;49:115-20. http://dx.doi.org/ 10.1016/j.jcv.2010.07.007

26. Yoo H, Gu SH, Jung J, Song DH, Yoon C, Hong DJ, et al. Febrile respiratory illness associated with human adenovirus type 55 in South Korea military, 2014-2016. Emerg Infect Dis. 2017;23:1016-20. http://dx.doi.org/10.3201/eid2306.161848

27. Barker JH, Luby JP, Sean Dalley A, Bartek WM, Burns DK, Erdman DD. Fatal type 3 adenoviral pneumonia in immunocompetent adult identical twins. Clin Infect Dis. 2003; 37:e142-6. http://dx.doi.org/10.1086/379127
28. Lewis PF, Schmidt MA, Lu X, Erdman DD, Campbell M, Thomas A, et al. A community-based outbreak of severe respiratory illness caused by human adenovirus serotype 14 . J Infect Dis. 2009;199:1427-34. http://dx.doi.org/10.1086/ 598521

29. Ludwig SL, Brundage JF, Kelley PW, Nang R, Towle C, Schnurr DP, et al. Prevalence of antibodies to adenovirus serotypes 4 and 7 among unimmunized US Army trainees: results of a retrospective nationwide seroprevalence survey. J Infect Dis. 1998;178:1776-8. http://dx.doi.org/10.1086/314498

30. Sanchez JL, Binn LN, Innis BL, Reynolds RD, Lee T, Mitchell-Raymundo F, et al. Epidemic of adenovirus-induced respiratory illness among US military recruits: epidemiologic and immunologic risk factors in healthy, young adults. J Med Virol. 2001;65:710-8. http://dx.doi.org/10.1002/jmv.2095

31. Trei JS, Johns NM, Garner JL, Noel LB, Ortman BV, Ensz KL, et al. Spread of adenovirus to geographically dispersed military installations, May-October 2007. Emerg Infect Dis. 2010;16:76975. http://dx.doi.org/10.3201/eid1605.091633

Address for correspondence: Hee Jin Cheong, Korea University College of Medicine, Division of Infectious Diseases, Department of Internal Medicine, Guro Hospital, Gurodong-ro 148, Guro-gu (08308) Seoul, South Korea; email: heejinmd@korea.ac.kr

\title{
etymologia
}

\section{Cytokines [si'to-kīnes]}

Thomas J. Gryczan

$F_{c}^{r}$ rom the Greek cyto (cavity or cell) and kine (movement), cytokines are proteins involved in cell signaling and function as immunomodulating agents. Cytokines are produced by immune cells (e.g., macrophages, B and T lymphocytes, mast cells, neutrophils, natural killer cells), endothelial cells, fibroblasts, and stromal cells.

Although the term cytokine had not yet even been defined, interferon- $\alpha$, the first cytokine known, was identified in 1957 as a protein that interfered with virus

\section{Sources}

1. Cohen S, Bigazzi PE, Yoshida T. Commentary. Similarities of $\mathrm{T}$ cell function in cell-mediated immunity and antibody production. Cell Immunol. 1974;12:150-9. http://dx.doi.org/ 10.1016/0008-8749(74)90066-5

2. Dumonde DC, Wolstencroft RA, Panayi GS, Matthew M, Morley J, Howson WT. Lymphokines: non-antibody mediators of cellular immunity generated by lymphocyte activation. Nature. 1969;224:38-42. http://dx.doi.org/10.1038/224038a0

3. Gordon J, MacLean LD. A lymphocyte-stimulating factor produced in vitro. Nature. 1965;208:795-6. http://dx.doi.org/10.1038/208795a0 replication. Activities of interferon- $\gamma$ and interleukin-2 were identified in 1965. Macrophage migratory inhibitory factor was identified in 1966. In 1969, Dumonde and colleagues proposed the term lymphokine to describe proteins secreted from lymphocytes. Proteins derived from macrophages and monocytes were later called monokines. In 1974, Cohen and colleagues reported production of macrophage migration inhibitory factors in virus-infected fibroblasts, which led (finally) to proposal of the term cytokine.

4. Isaacs A, Lindenmann J. Virus interference. I. The interferon. Proc R Soc Lond B Biol Sci. 1957;147:258-67. http://dx.doi.org/10.1098/rspb.1957.0048

5. Kasakura S, Lowenstein L. A factor stimulating DNA synthesis derived from the medium of leukocyte cultures. Nature. 1965;208:794-5. http://dx.doi.org/ 10.1038/208794a0

6. Wheelock EF. Interferon-like virus-inhibitor induced in human leukocytes by phytohemagglutinin. Science. 1965;149:310-1. http://dx.doi.org/10.1126/ science.149.3681.310

Address for correspondence: Thomas J. Gryczan, EID Journal, Centers for Disease Control and Prevention, 1600 Clifton Rd NE, Mailstop C19, Atlanta, GA 30329-4027, USA; email: dtq6@cdc.gov 